\title{
Intermittent and continuous faecal markers in short-term metabolic balance studies in young women
}

\author{
BY SUSAN J. SHARPE AND MARION F. ROBINSON \\ Department of Nutrition, University of Otago School of Home Science, \\ Dunedin, New Zealand
}

(Received 18 August 1969-Accepted 29 December 1969)

\footnotetext{
I The continuous faecal marker chromic oxide, $\mathrm{Cr}_{2} \mathrm{O}_{3}$, and the intermittent marker brilliant blue were used together in metabolic balance studies of calcium and magnesium in two young women.

2. Faecal output was derived by four methods: no marker, brilliant blue, $\mathrm{Cr}_{2} \mathrm{O}_{3}$, or both brilliant blue and $\mathrm{Cr}_{2} \mathrm{O}_{3}$.

3. Balances of $\mathrm{Ca}$ and $\mathrm{Mg}$ derived by the four methods of obtaining faecal output were compared.

4. Recovery of ingested $\mathrm{Cr}_{2} \mathrm{O}_{3}$ in the faeces appeared complete in experiments on three further subjects, with only a negligible amount being excreted in the urine.

5. Simultaneous use of both types of marker is recommended for short-term balance studies of nutrients such as $\mathrm{Ca}$ and $\mathrm{Mg}$ which are not readily absorbed.
}

In metabolic studies, it is necessary to identify and measure the faecal output from a particular intake of food. For nutrients such as sodium and potassium the faecal output represents such a small proportion of the intake that its measurement may even be neglected (Elkinton \& Danowski, I955), but the faecal output of nutrients which are not readily absorbed from the gastro-intestinal tract, such as calcium, magnesium and some of the trace elements, is considerable.

In most balance studies, particularly short-term studies, two types of faecal markers are used : an intermittent marker such as charcoal, carmine, or brilliant blue, which is administered at the beginning and end of an experimental period, thereby distinguishing the faeces related to that period of feeding (Lusk, r93 I; McCance \& Widdowson, 1942; Lutwak \& Burton, I964), and secondly a continuous marker such as polyethylene glycol, chromic oxide or barium sulphate, which defines the quantity of faeces related to a given quantity of food, assuming that the marker and the nutrient being studied have similar transit times through the alimentary tract (Whitby \& Lang, I960; Rampone, I968; Figueroa, Jordan \& Bassett, I968; Borgström, Dahlqvist, Lundh \& Sjövall, 1957). Davignon, Simmonds \& Ahrens (1968) defined the criteria for an ideal marker, following their extensive investigation of the use of chromic oxide as an internal standard. Rose ( 1964 ) found the simultaneous use of carmine and chromic oxide particularly valuable in metabolic studies involving a change of diet or therapy (Hargreaves \& Rose, 1965).

It is possible to measure the faecal output of a nutrient without using a marker, especially in long balance studies (Isaksson \& Sjögren, 1967); the purpose of this investigation was to discover how much the measurement of faecal output could be improved by using the intermittent marker brilliant blue, the continuous marker 
chromic oxide, or both together for the measurement of the metabolic balances of calcium and magnesium. Each marker revealed its own peculiar advantages in $27 \mathrm{~d}$ balance studies on two young women, and in order to derive the greatest benefit the markers needed to be used together. The criteria of Davignon et al. (1968) were applied to our studies, namely, that an ideal marker should be non-absorbable, nontoxic and easy to measure; it should be dispersed uniformly relative to the faecal constituent of interest in the particular investigation, and also a steady state should be attained rapidly in which, on the average, excretion and intake are equal. The recovery of ingested chromic oxide in the faeces was measured in three further subjects, as well as its excretion in the urine; the results indicated that a negligible amount of chromium had been absorbed.

\section{EXPERIMENTAL}

\section{Balance study}

The young women students, subject $G$ and subject $M$, were two of the subjects in the balance study of metabolic effects of meal frequency, for which full details of diet and procedure have already been given (Swindells, Holmes \& Robinson, I968). The subjects ate a uniform diet for $27 \mathrm{~d}$; the experimental regime was divided into three $6 \mathrm{~d}$ experimental periods $(2,3$ and 4$)$, with a $6 \mathrm{~d}$ preliminary period (I) and a $3 \mathrm{~d}$ after-period (5). The same daily amount of food was divided into the appropriate number of equal-sized meals; three meals were eaten daily in periods I, 3 and 5 , two meals in period 2 (gorging) and nine meals in period 4 (nibbling). The concentrations of $\mathrm{Ca}$ and $\mathrm{Mg}$ were measured in the diet and in the $24 \mathrm{~h}$ collections of urine.

\section{Faeces}

Two gelatin capsules, each containing $5 \circ \mathrm{mg}$ brilliant blue marker (FD \& $\mathrm{C}$ Blue No. I) and $200 \mathrm{mg}$ methyl cellulose, were taken during the evening following the last meal of each period; the presence of green faeces marked the beginning of the next period (Lutwak \& Burton, 1964). Chromic oxide (reagent grade $\mathrm{Cr}_{2} \mathrm{O}_{3} ;$ British Drug Houses Ltd) was purified to remove dichromate by the method of Whitby \& Lang (1960). Gelatin capsules were filled by hand to contain $500 \mathrm{mg} \pm 2 \mathrm{mg} \mathrm{Cr}_{2} \mathrm{O}_{3}$ and one capsule was taken three times daily, with the three meals in periods $\mathrm{I}, 3$ and 5 , and at about the same times of day in periods 2 and 4 . Administration of $\mathrm{Cr}_{2} \mathrm{O}_{3}$ began on day 4 of period $\mathrm{I}$ and continued until day 3 of period 5 ; faeces were collected during this time until the brilliant blue taken at the end of period 4 had appeared.

Each stool was collected, weighed and dried under an infrared lamp, after which it was ground to a fine powder. The recorded weight of the stool included the weight of faeces on the toilet paper. Two-thirds of each stool was pooled for each period; the remainders of the stools were kept for analyses of separate stools.

\section{Recovery of $\mathrm{Cr}_{2} \mathrm{O}_{3}$}

Subjects $\mathrm{R}, \mathrm{H}$, and $\mathrm{S}$ swallowed three capsules of $\mathrm{Cr}_{2} \mathrm{O}_{3} / \mathrm{d}$ for $2 \mathrm{~d}$, equivalent to a total intake of $3 . \circ \mathrm{Cr}_{2} \mathrm{O}_{3}$. Faeces were collected for those $2 \mathrm{~d}$ and the subsequent to $\mathrm{d}$; 
each stool was analysed for $\mathrm{Cr}$ and the recovery of ingested $\mathrm{Cr}_{2} \mathrm{O}_{3}$ determined. The factor used for converting $\mathrm{Cr}$ into $\mathrm{Cr}_{2} \mathrm{O}_{3}$ was $\mathrm{I}_{4} 6$.

Recovery of $\mathrm{Cr}$ from purified $\mathrm{Cr}_{2} \mathrm{O}_{3}$ was measured in six samples taken from capsules; the mean recovery was 101 \% (range 100-103\%).

\section{Excretion of $\mathrm{Cr}$ in urine}

As in the previous experiment, subjects $\mathrm{H}$ and $\mathrm{S}$ swallowed three capsules of $\mathrm{Cr}_{2} \mathrm{O}_{3}$ daily for $2 \mathrm{~d} ; 24 \mathrm{~h}$ urine samples were collected for $7 \mathrm{~d}$, from the day before $\mathrm{Cr}_{2} \mathrm{O}_{3}$ was ingested until $4 \mathrm{~d}$ afterwards. Concentration of $\mathrm{Cr}$ was estimated in each day's urine.

For each period of the balance study, the concentration of $\mathrm{Cr}$ was measured in the pooled urines for subject $G$ and subject $M$; the urines were pooled by mixing equal proportions of their $24 \mathrm{~h}$ volumes.

\section{Analytical methods}

Chromium was determined with a Techtron AA-roo atomic absorption spectrophotometer. Faeces were analysed by the method which Williams, David \& Iismaa (I962) used for faecal samples in pasture experiments. Interference from small differences in the $\mathrm{Ca}$ and $\mathrm{Mg}$ concentrations of the samples was suppressed by spraying test and standard solutions containing $500 \mathrm{ppm} \mathrm{Ca}$, but silicate was not added to standard solutions since human faeces contain little silicate (Sollmann, I926). For urine, $200 \mathrm{ml}$ were dried and ashed at $600^{\circ} ; \mathrm{Cr}$ present was oxidized with $\mathrm{HNO}_{3}$ and $\mathrm{KMnO}_{4}$, extracted into isobutyl ketone and sprayed into the flame (Feldman, Knoblock \& Purdy, I967). Blank and standard solutions were similarly treated.

$\mathrm{Ca}$ and $\mathrm{Mg}$ were measured in the diet, faeces and urine by atomic absorption spectroscopy. Urines were analysed directly, but for the diet and faeces an acid extract of the ashed sample was first prepared. Interference by phosphate with the determination of $\mathrm{Ca}$ was suppressed by spraying solutions containing a $\mathrm{I} \%$ concentration of lanthanum (Willis, $196 \mathrm{r}$ ), and all solutions analysed for $\mathrm{Mg}$ were acidified to contain o. I N-HCl (Dawson \& Heaton, I96r).

\section{RESULTS}

\section{Faecal output}

Brilliant blue was noticed first in the faeces of subject $G$ on days $I, 3,4$ and 2 of periods 2, 3, 4 and 5 , respectively, and in the faeces of subject $M$ on days 2, 2, 5 and 8 , respectively. These days marked the beginning of faecal collection during periods 2, 3,4 and 5 for each subject. Table I gives the dried weight of faeces, the percentage dry matter and the concentrations of $\mathrm{Ca}, \mathrm{Mg}$ and $\mathrm{Cr}_{2} \mathrm{O}_{3}$ in the pooled dried faeces for each period. Values for period I represent the composition of the faeces collected from day 4 until period 2 began, and those for period 5 represent the composition of faeces collected at the end of the study after the marker given at the end of period 4 had appeared. Fig. $\mathrm{I}$ gives the concentrations of $\mathrm{Ca}, \mathrm{Mg}$ and $\mathrm{Cr}$ in the individual stools of the subjects; the concentrations of $\mathrm{Ca}$ and $\mathrm{Mg}$ in the dried faeces varied little throughout the experiment. 
Table I. Weight and composition of faeces in young women for each period of the experiment

(Period I was the preliminary period and period 5 the after-period)

\begin{tabular}{|c|c|c|c|c|c|c|}
\hline \multirow[b]{2}{*}{ Subject } & \multirow[b]{2}{*}{ Period } & \multirow[b]{2}{*}{$\begin{array}{c}\text { Dried } \\
\text { faecal } \\
\text { weight } \\
\text { (g/period) }\end{array}$} & \multicolumn{4}{|c|}{ Composition of faeces } \\
\hline & & & $\begin{array}{c}\text { Dry } \\
\text { matter } \\
\text { (\% wet } \\
\text { faeces) }\end{array}$ & $\begin{array}{c}\mathrm{Ca} \\
\text { (mg/g } \\
\text { dried } \\
\text { faeces) }\end{array}$ & $\begin{array}{c}\mathrm{Mg} \\
\text { (mg/g } \\
\text { dried } \\
\text { faeces) }\end{array}$ & $\begin{array}{c}\mathrm{Cr}_{2} \mathrm{O}_{3} \\
\text { (mg/g } \\
\text { dried } \\
\text { faeces) }\end{array}$ \\
\hline \multirow[t]{5}{*}{ G } & $\mathbf{I}$ & 50 & 25 & 33 & $5 \cdot 5$ & 18 \\
\hline & 2 & I 14 & 27 & 32 & $5 \cdot 6$ & 85 \\
\hline & 3 & 123 & 28 & $3^{I}$ & $5 \cdot 8$ & 82 \\
\hline & 4 & 61 & 29 & 32 & $5 \cdot 7$ & 90 \\
\hline & 5 & 30 & 32 & 33 & $5 \cdot 5$ & 85 \\
\hline \multirow[t]{5}{*}{ M } & $\mathbf{I}$ & 68 & 28 & $3 \mathrm{I}$ & $8 \cdot 5$ & I 8 \\
\hline & 2 & 80 & 30 & 35 & $7 \cdot 5$ & 78 \\
\hline & 3 & I I 8 & 33 & 37 & $7 \cdot 9$ & 88 \\
\hline & 4 & 35 & 32 & 36 & $7 \cdot 8$ & 92 \\
\hline & 5 & 95 & 32 & 36 & $7 \cdot 9$ & 85 \\
\hline
\end{tabular}

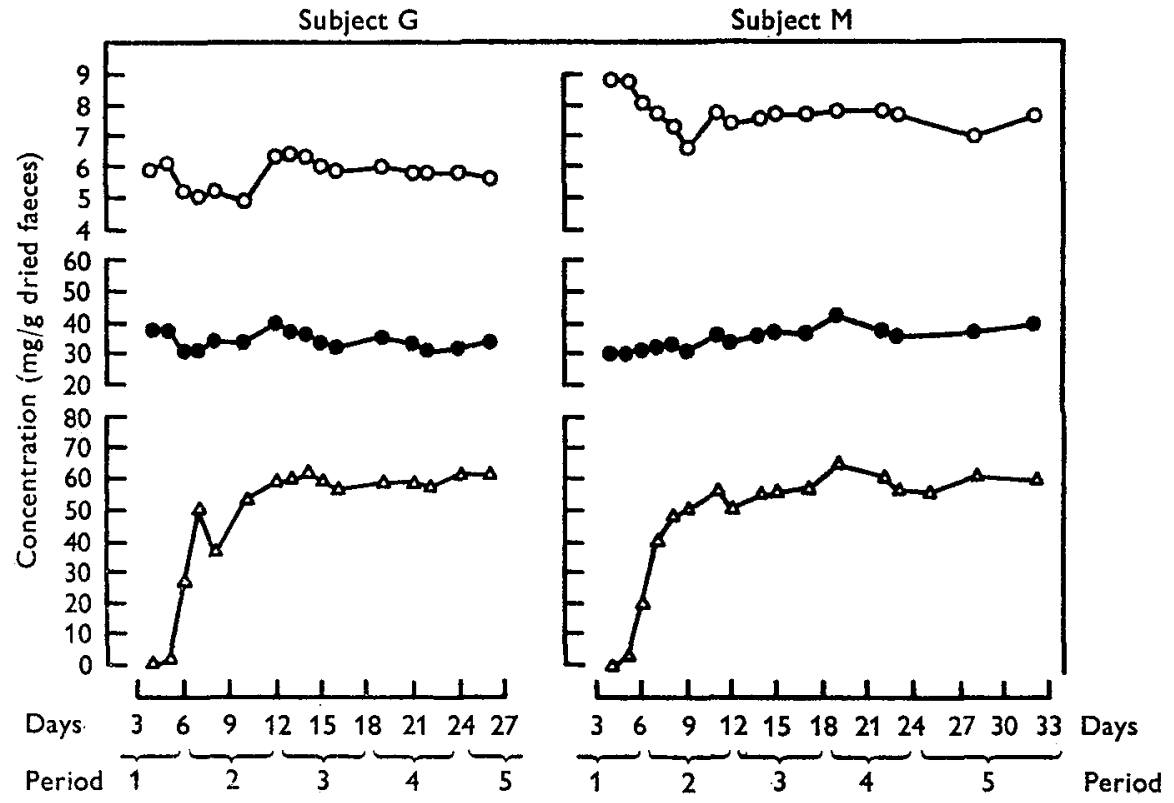

Fig. I. Concentration ( $\mathrm{mg} / \mathrm{g}$ dried faeces) of magnesium $(\bigcirc)$, calcium $(\bigcirc)$ and chromium $(\triangle)$ in the individual stools of two young women.

In this study the faecal outputs of $\mathrm{Ca}$ and $\mathrm{Mg}$ have been estimated for the three experimental periods by four methods (Table 2 ).

(a) No marker: the faecal output was derived from the weight and composition of the faeces collected during the $6 \mathrm{~d}$ of each period.

(b) Brilliant blue: the beginning and end of faecal periods were 'marked', so that the faeces weighed and analysed were those produced from a particular period of feeding. 
(c) Chromic oxide: the weight of faeces collected as in method (a) was adjusted by the ratio of the $9^{\circ} \circ \mathrm{g} \mathrm{Cr}_{2} \mathrm{O}_{3}$ ingested during each period to the amount of $\mathrm{Cr}_{2} \mathrm{O}_{3}$ recovered in the faeces.

(d) Brilliant blue and chromic oxide: the weight of faeces collected during each 'marked' period by method $(b)$ was adjusted according to its content of $\mathrm{Cr}_{2} \mathrm{O}_{3}$ as in method $(c)$.

The calculations were made for methods $(a)$ and $(c)$ from the results of analyses of individual stools, and for methods $(b)$ and $(d)$ from analyses of pooled stools. The dried faecal weight/d was obtained by dividing the dried weight/period by 6 , the number of days in each period of feeding.

Table 2. Daily faecal output of calcium and magnesium $(g)$ by young women, derived by four methods of calculating dried faecal weight $(\mathrm{g})$

\begin{tabular}{|c|c|c|c|c|c|c|c|c|c|c|}
\hline \multirow[b]{2}{*}{ Subject } & \multirow{2}{*}{$\begin{array}{l}\text { Method of } \\
\text { calculation }\end{array}$} & \multicolumn{3}{|c|}{$\begin{array}{l}\text { Dry weight } \\
\text { in period }\end{array}$} & \multicolumn{3}{|c|}{$\begin{array}{c}\mathrm{Ca} \\
\text { in period }\end{array}$} & \multicolumn{3}{|c|}{$\underbrace{\mathrm{Mg}}_{\text {in period }}$} \\
\hline & & 2 & 3 & 4 & 2 & 3 & 4 & 2 & 3 & 4 \\
\hline \multirow[t]{4}{*}{ G } & No marker & 14 & 16 & 20 & 0.46 & 0.56 & 0.68 & 0.07 & 0.10 & 0.12 \\
\hline & Brilliant blue & 19 & 20 & 10 & $0.6 I$ & 0.64 & 0.33 & 0.11 & 0.12 & 0.06 \\
\hline & $\mathrm{Cr}_{2} \mathrm{O}_{3}$ & I8 & 17 & 17 & 0.66 & 0.59 & 0.57 & 0.10 & 0.10 & 0.10 \\
\hline & $\begin{array}{l}\mathrm{Cr}_{2} \mathrm{O}_{3}+ \\
\text { brilliant blue }\end{array}$ & I8 & I8 & 17 & 0.56 & 0.57 & 0.53 & 0.10 & O.I I & 0.10 \\
\hline \multirow[t]{4}{*}{$\mathbf{M}$} & No marker & I 5 & ro & I 5 & 0.53 & 0.36 & 0.57 & O.I I & 0.07 & 0.12 \\
\hline & Brilliant blue & $\mathrm{r}_{3}$ & 20 & 6 & 0.47 & 0.72 & 0.21 & 0.10 & O.I5 & 0.05 \\
\hline & $\mathrm{Cr}_{2} \mathrm{O}_{3}$ & I9 & 18 & I7 & 0.68 & 0.68 & 0.66 & 0.14 & 0.13 & 0.13 \\
\hline & $\begin{array}{l}\mathrm{Cr}_{2} \mathrm{O}_{3}+ \\
\text { brilliant blue }\end{array}$ & I9 & 17 & I6 & 0.67 & 0.63 & 0.59 & 0.13 & 0.13 & 0.13 \\
\hline
\end{tabular}

Table 3. Daily intake and urinary excretion of calcium and magnesium ( $g$ ) by young women in periods 2, 3 and 4

(Mean values with standard deviations in parentheses)

\begin{tabular}{|c|c|c|c|c|}
\hline \multirow[b]{3}{*}{ Subject } & \multicolumn{4}{|c|}{ Calcium } \\
\hline & & \multicolumn{3}{|c|}{$\begin{array}{l}\text { Urinary excretion } \\
\text { in period }\end{array}$} \\
\hline & Intake & 2 & 3 & 4 \\
\hline G & 0.88 & $\begin{array}{c}0.21 \\
(0.02)\end{array}$ & $\begin{array}{c}0.16 \\
(0.02)\end{array}$ & $\begin{array}{c}0.15 \\
(0.05)\end{array}$ \\
\hline $\mathbf{M}$ & 0.90 & $\begin{array}{l}0.21 \\
(0.02)\end{array}$ & $\begin{array}{l}0.23 \\
(0.03)\end{array}$ & $\begin{array}{l}0.26 \\
(0.03)\end{array}$ \\
\hline
\end{tabular}

\begin{tabular}{|c|c|c|c|}
\hline \multirow[b]{3}{*}{ Intake } & \multicolumn{3}{|c|}{ Magnesium } \\
\hline & \multicolumn{3}{|c|}{$\begin{array}{l}\text { Urinary excretion } \\
\text { in period }\end{array}$} \\
\hline & 2 & 3 & 4 \\
\hline 0.25 & $\begin{array}{c}0.12 \\
(0.01)\end{array}$ & $\begin{array}{c}0.11 \\
(0.02)\end{array}$ & $\begin{array}{c}0.11 \\
(0.03)\end{array}$ \\
\hline 0.27 & $\begin{array}{c}0.12 \\
(0.02)\end{array}$ & $\begin{array}{c}0.11 \\
(0.01)\end{array}$ & $\begin{array}{c}0.12 \\
(0.01)\end{array}$ \\
\hline
\end{tabular}

The daily dried weights showed considerable variation from period to period with method $(a)$ and also with method $(b)$, but this was reduced when the weights were corrected for the recovery of $\mathrm{Cr}_{2} \mathrm{O}_{3}$ in methods $(c)$ and $(d)$. Since the concentrations of $\mathrm{Ca}$ and $\mathrm{Mg}$ did not alter appreciably throughout the experiment (Fig. I, Table $\mathrm{I}$ ), the variations in faecal weight were reflected in the variations in faecal output of $\mathrm{Ca}$ and of Mg (Table 2). 
Table 4. Magnesium balances $(\mathrm{g} / \mathrm{d})$ for young women, calculated by four methods of deriving faecal output

\begin{tabular}{|c|c|c|c|c|}
\hline \multirow[b]{2}{*}{ Subject } & \multirow[b]{2}{*}{ Method of calculation } & \multicolumn{3}{|c|}{$\begin{array}{l}\mathrm{Mg} \text { balance } \\
\text { in period }\end{array}$} \\
\hline & & 2 & 3 & 4 \\
\hline G & $\begin{array}{l}\text { No marker } \\
\text { Brilliant blue } \\
\mathrm{Cr}_{2} \mathrm{O}_{3} \\
\mathrm{Cr}_{2} \mathrm{O}_{3}+\text { brilliant blue }\end{array}$ & $\begin{array}{l}0.06 \\
0.02 \\
0.04 \\
0.03\end{array}$ & $\begin{array}{l}0.04 \\
0.02 \\
0.04 \\
0.03\end{array}$ & $\begin{array}{l}0.02 \\
0.08 \\
0.04 \\
0.04\end{array}$ \\
\hline $\mathbf{M}$ & $\begin{array}{l}\text { No marker } \\
\text { Brilliant blue } \\
\mathrm{Cr}_{2} \mathrm{O}_{3} \\
\mathrm{Cr}_{2} \mathrm{O}_{3}+\text { brilliant blue }\end{array}$ & $\begin{array}{l}0.04 \\
0.05 \\
0.00 \\
0.01\end{array}$ & $\begin{array}{l}0.09 \\
0.01 \\
0.03 \\
0.03\end{array}$ & $\begin{array}{l}0.03 \\
0.10 \\
0.02 \\
0.02\end{array}$ \\
\hline
\end{tabular}

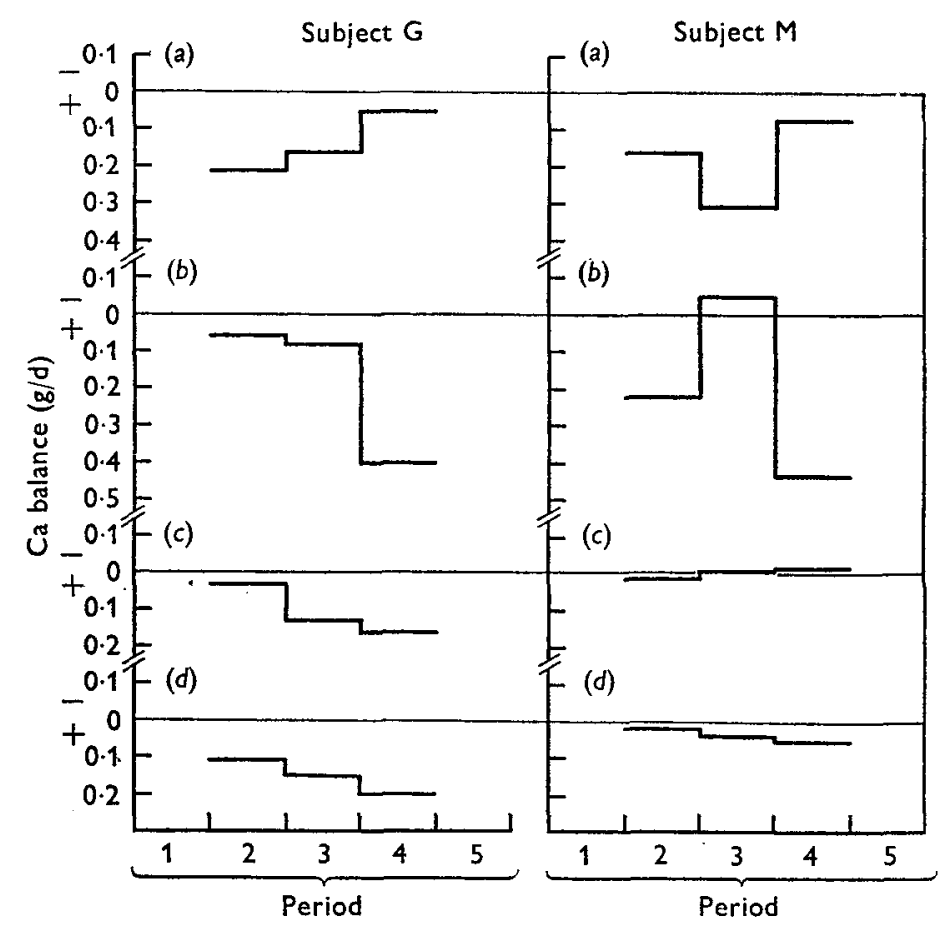

Fig. 2. Calcium balances for two young women calculated by the four methods of deriving faecal output: (a) no marker; (b) brilliant blue; (c) $\mathrm{Cr}_{2} \mathrm{O}_{3} ;(d)$ both brilliant blue and $\mathrm{Cr}_{2} \mathrm{O}_{3}$. Positive balances are plotted downwards.

\section{Balance study}

Table 3 contains the values for the intake of $\mathrm{Ca}$ and $\mathrm{Mg}$ by the two subjects. Subject $M$ ingested more meat loaf and drank some of her daily allowance of fluid as black coffee, which accounted for her slightly greater intake of both $\mathrm{Ca}$ and $\mathrm{Mg}$ (Swindells et al. r968). Mean urinary excretion of $\mathrm{Ca}$ and $\mathrm{Mg}$ for each period is also given in Table 3 , and these values with those for the faecal output made up the 'total output' of $\mathrm{Ca}$ and $\mathrm{Mg}$; no correction was made for dermal loss of either element. 
The balance was estimated by the four methods of deriving the faecal output; the $\mathrm{Mg}$ balances are listed in Table 4, and the Ca balances are illustrated in Fig. 2.

Because the intake was constant and the urinary output varied little, the balances for $\mathrm{Ca}$ and $\mathrm{Mg}$ were largely influenced by the faecal weight for each period. In contrast to the balances obtained when no marker had been used, or when brilliant blue was used alone, the balances derived with the aid of $\mathrm{Cr}_{2} \mathrm{O}_{3}$ agreed from period to period; this was especially noticeable for subject $M$. Although the use of the intermittent marker as well as $\mathrm{Cr}_{2} \mathrm{O}_{3}$ did not alter the measured balance appreciably, it indicated the time taken for food to pass through the alimentary tract. This time increased as the study progressed, particularly in subject $M$ for whom the last two doses of brilliant blue took 5 and $8 \mathrm{~d}$ to appear.

(a)

(b)

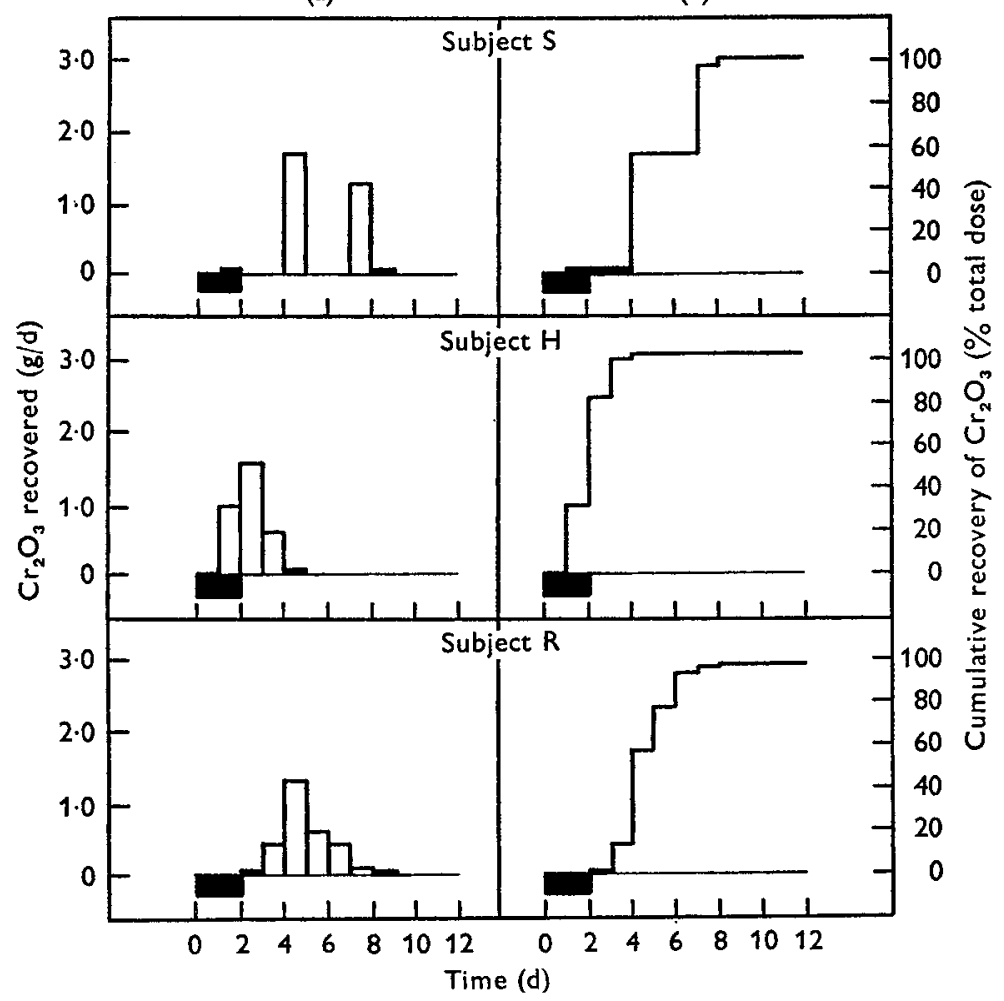

Fig. 3. Recovery of $\mathrm{Cr}_{2} \mathrm{O}_{3}$ in the stools of three young women during the $2 \mathrm{~d}(\boldsymbol{D}) \mathrm{Cr}_{2} \mathrm{O}_{3}(\mathrm{I} \cdot 5 \mathrm{~g} / \mathrm{d})$ was ingested and the subsequent ro $\mathrm{d}$. (a) amount recovered; $(b)$ cumulative recovery.

\section{Recovery of $\mathrm{Cr}_{2} \mathrm{O}_{3}$}

Although the use of $\mathrm{Cr}_{2} \mathrm{O}_{3}$ improved the reproducibility of the $\mathrm{Ca}$ and $\mathrm{Mg}$ balances in the three periods, the total recovery of $\mathrm{Cr}_{2} \mathrm{O}_{3}$ was incomplete, $83 \%$ for subject $\mathrm{G}$ and $85 \%$ for subject $\mathrm{M}$. Whitby \& Lang (1960) reported a mean recovery of $93 \%$ for six patients (range 88-98\%), and later Rose (1964) obtained the same value (93\%) for his twenty-one studies (range 80-ro3\%). Both workers suggested that incomplete 
collection of faeces was the cause, with possibly some loss on the toilet paper. In our study, faecal matter left on toilet paper was carefully measured and it was usually less than $0 \cdot 1 \mathrm{~g}$.

Fig. 3 illustrates the course of recovery of $3.0 \mathrm{~g} \mathrm{Cr}_{2} \mathrm{O}_{3}$ ingested by subjects $\mathrm{R}$, $\mathrm{H}$ and $\mathrm{S}$. The pattern of elimination of faecal $\mathrm{Cr}_{2} \mathrm{O}_{3}$ differed in each subject; for subject $\mathrm{R}$ who had daily stools the transit time of $\mathrm{Cr}_{2} \mathrm{O}_{3}$ was long, for subject $\mathrm{H}$ it was short, and subject $\mathrm{S}$ tended to be constipated. No chromic oxide was detected in faeces of subject $\mathrm{H}_{4} \mathrm{~d}$ after ingestion, but both subjects $\mathrm{R}$ and $\mathrm{S}$ had $\mathrm{Cr}_{2} \mathrm{O}_{3}$ in their faeces $3 \mathrm{~d}$ later on day 9 . The recoveries were 97 , 100 and $104 \%$ for subjects $\mathrm{R}, \mathrm{S}$ and $H$, respectively. Considering that these values were obtained from the sum of many measurements and that the recovery of $\mathrm{Cr}$ from purified $\mathrm{Cr}_{2} \mathrm{O}_{3}$ was $\mathrm{IOI} \%$, it seemed reasonable to conclude that recovery of $\mathrm{Cr}_{2} \mathrm{O}_{3}$ had been complete.

Table 5. Urinary chromium excretion following ingestion of $\mathrm{Cr}_{2} \mathrm{O}_{3}$ by young women

\begin{tabular}{|c|c|c|c|c|}
\hline \multirow[b]{2}{*}{ Subject } & \multirow[b]{2}{*}{ Day } & \multirow[b]{2}{*}{$\begin{array}{c}\mathrm{Cr}_{2} \mathrm{O}_{3} \text { ingested } \\
(\mathrm{g} / \mathrm{d})\end{array}$} & \multicolumn{2}{|c|}{ Urinary $\mathrm{Cr}$ excretion } \\
\hline & & & $\begin{array}{c}\text { Concentration } \\
(\mu \mathrm{g} / \mathrm{l})\end{array}$ & $\begin{array}{l}\text { Output } \\
(\mu \mathrm{g} / \mathrm{d})\end{array}$ \\
\hline \multirow[t]{7}{*}{$\mathbf{H}$} & I & - & 9 & 23 \\
\hline & 2 & $I \cdot 5$ & 7 & 20 \\
\hline & 3 & $I \cdot 5$ & 4 & 13 \\
\hline & 4 & - & 4 & 8 \\
\hline & 5 & - & 5 & I 4 \\
\hline & 6 & - & 9 & 25 \\
\hline & 7 & - & 7 & I 6 \\
\hline \multirow[t]{7}{*}{$S$} & $\mathbf{I}$ & - & ro & I3 \\
\hline & 2 & $1 \cdot 5$ & I3 & 19 \\
\hline & 3 & $\mathrm{I} \cdot 5$ & 54 & 73 \\
\hline & 4 & - & 14 & I I \\
\hline & 5 & - & 5 & 6 \\
\hline & 6 & - & $\mathbf{I} \mathbf{I}$ & 16 \\
\hline & 7 & - & 8 & I I \\
\hline
\end{tabular}

\section{Urinary excretion of chromium}

The concentration of $\mathrm{Cr}$ in the urine was so low that precise measurement was impossible in the balance study. Sufficient urine for each estimation $(200 \mathrm{ml})$ could only be obtained by pooling urines for each period; concentrations of $\mathrm{Cr}$ in urine varied between 4 and $25 \mu \mathrm{g} / 1$ for both subjects, corresponding to an output of $4-25 \mu \mathrm{g} / \mathrm{d}$ (see Table 6, Swindells et al. I968). Table 5 gives the urinary excretion of $\mathrm{Cr}$ following ingestion of $3^{\circ} \circ \mathrm{g} \mathrm{Cr}_{2} \mathrm{O}_{3}$. The concentration of $\mathrm{Cr}(4-9 \mu \mathrm{g} / \mathrm{l})$ and the amount excreted each day $(8-25 \mu \mathrm{g})$ were low for subject $\mathrm{H}$, for whom the transit time for $\mathrm{Cr}_{2} \mathrm{O}_{3}$ had previously been short (Fig. 3). In subject $\mathrm{S}$, however, for whom the transit time was long, the concentration of $\mathrm{Cr}$ increased suddenly on the 2 nd day of administration of $\mathrm{Cr}_{2} \mathrm{O}_{3}$ to a value four to five times as high, but even this was only slightly above the normal range for $\mathrm{Cr}$ excretion of $20-40 \mu \mathrm{g} / 1$ reported by Schroeder (I968).

\section{Steady state of faecal output}

Davignon et al. (I968) defined 'ideality of $\mathrm{Cr}_{2} \mathrm{O}_{3}$ excretion' as the achievement of a steady state in which not only had the $\mathrm{Cr}_{2} \mathrm{O}_{3}$ concentration in the faeces reached 
a plateau but also the mean daily output of $\mathrm{Cr}_{2} \mathrm{O}_{3}$ was $90 \%$ or more of the intake. Although the $\mathrm{Cr}_{2} \mathrm{O}_{3}$ concentration might have reached a plateau in some subjects from whom the cumulative recovery was less than $90 \%$, they contended that the true steady state had not been reached since an appreciable amount of marker had been retained. It would be invalid to use $\mathrm{Cr}_{2} \mathrm{O}_{3}$ as a reference marker for correction of faecal weights in these 'non-ideal' subjects. Davignon et al. (I 968) calculated the faecal $\mathrm{Cr}_{2} \mathrm{O}_{3}$ concentration, the $\mathrm{Cr}_{2} \mathrm{O}_{3}$ balance and the cumulative recovery of $\mathrm{Cr}_{2} \mathrm{O}_{3}$ for each period. Similar calculations have been made for subjects $G$ and $M$ from the composition of the

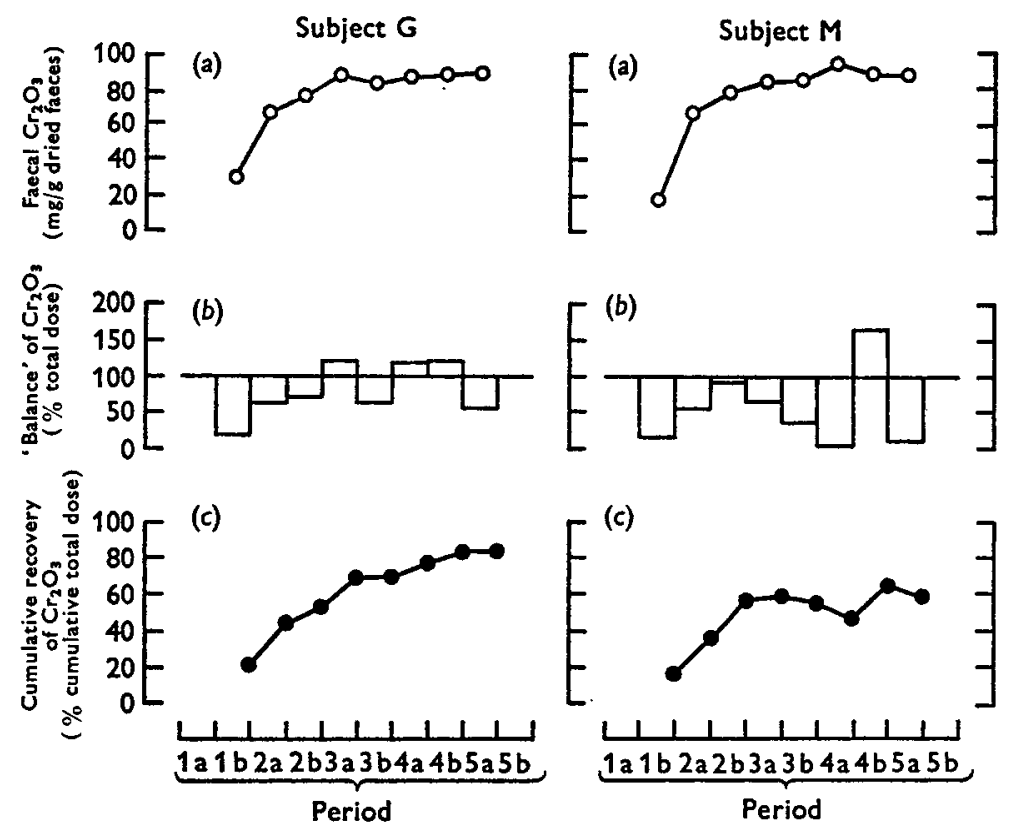

Fig. 4. Faecal excretion of $\mathrm{Cr}_{2} \mathrm{O}_{3}$ in two young women for each $3 \mathrm{~d}$ period. $\mathrm{Cr}_{2} \mathrm{O}_{3}$ was administered from beginning of period $\mathrm{rb}$ until day 3 of period $5 \mathrm{a}$.

individual stools but for $3 \mathrm{~d}$ periods, which is half the time of our $6 \mathrm{~d}$ experimental periods; these 'half-periods' have been designated as $(a)$ and $(b)$ corresponding to days I-3 and days $4-6$ of each period, respectively. Fig. 4 shows that for both subjects the $\mathrm{Cr}_{2} \mathrm{O}_{3}$ concentrations had reached a plateau by period $2 \mathrm{~b}$. For subject $\mathrm{G}$, the faecal excretion of $\mathrm{Cr}_{2} \mathrm{O}_{3}$ (or $\mathrm{Cr}_{2} \mathrm{O}_{3}$ balance) varied from 60 to $120 \%$ of the daily dose from periods $2 \mathrm{~b}-4 \mathrm{~b}$ and the mean daily output was $93 \%$ of the intake. However, for subject $\mathrm{M}$, only in period $4 \mathrm{~b}$ was the excretion of $\mathrm{Cr}_{2} \mathrm{O}_{3}$ greater than the intake, and the mean daily output from periods $2 \mathrm{~b}-4 \mathrm{~b}$ was $84 \%$ of the ingested $\mathrm{Cr}_{2} \mathrm{O}_{3}$. The cumulative recovery increased steadily throughout the balance period for subject $\mathrm{G}$ and was more than $80 \%$ when ingestion of $\mathrm{Cr}_{2} \mathrm{O}_{3}$ ceased, whereas for subject $\mathrm{M}$ it remained almost unchanged from period $2 \mathrm{~b}$ onwards at $60 \%$ of the total dose.

If the criteria of Davignon et al. (1968) were applied in our study, subject G would be called an 'ideal' subject and subject $M$ would not, with the inference that $\mathrm{Cr}_{2} \mathrm{O}_{3}$ was being retained. Referring back to Fig. $\mathrm{I}$, it will be seen that the excretion of 
$\mathrm{Ca}$ and $\mathrm{Mg}$ varied with that of $\mathrm{Cr}$ from day 4 and day 3 in period 2 for subjects $\mathrm{G}$ and $M$, respectively; correlation coefficients were calculated from these times until the ingestion of $\mathrm{Cr}_{2} \mathrm{O}_{3}$ was discontinued on day 3 of period 5 (Table 6). The significant correlations for subject $\mathrm{M}$, and for subject $\mathrm{G}$ (with the exception of $\mathrm{Ca}$ and $\mathrm{Cr}$ ), might suggest that $\mathrm{Cr}_{2} \mathrm{O}_{3}$ was uniformly dispersed relative to the faecal constituents (Davignon et al. I968), making it permissible to correct for the incomplete collection of faeces in the balance studies of both our subjects. Furthermore, the low recovery of $\mathrm{Cr}_{2} \mathrm{O}_{3}$ had possibly been caused by a slowing down of bowel function as the study progressed; this was demonstrated by the use of brilliant blue.

Table 6. Correlation coefficients for concentrations of calcium, magnesium and chromium in individual stools collected from young women during periods 2-5

$\begin{array}{cccc}\text { Subject } & \begin{array}{c}\text { Correlation } \\ \text { of }\end{array} & \begin{array}{c}\text { Correlation } \\ \text { coefficient }\end{array} & \begin{array}{c}\text { Significance } \\ P\end{array} \\ \mathrm{G} & \mathrm{Cr} \text { and } \mathrm{Ca} & 0.39 & \mathrm{NS}(0.20) \\ & \mathrm{Cr} \text { and } \mathrm{Mg} & 0.70 & 0.01 \\ \mathrm{Ca} \text { and } \mathrm{Mg} & 0.68 & 0.02 \\ \mathrm{M} & \mathrm{Cr} \text { and } \mathrm{Ca} & 0.96 & <0.001 \\ & \mathrm{Cr} \text { and } \mathrm{Mg} & 0.82 & 0.01 \\ & \mathrm{Ca} \text { and } \mathrm{Mg} & 0.75 & 0.02\end{array}$

NS, not significant.

\section{DISCUSSION}

Comparison of the results for the balances of $\mathrm{Ca}$ and $\mathrm{Mg}$ derived by the four methods confirmed the usefulness of $\mathrm{Cr}_{2} \mathrm{O}_{3}$ for measuring the faecal output. The question which now remains is whether it is an advantage to use an intermittent marker as well as $\mathrm{Cr}_{2} \mathrm{O}_{3}$.

First, by applying the criteria of Davignon et al. (1968) to the use of $\mathrm{Cr}_{2} \mathrm{O}_{3}$ alone in this study, it will be seen that $\mathrm{Cr}_{2} \mathrm{O}_{3}$ was easily estimated, and its recovery in the faeces appeared complete. The increase of $54 \mu \mathrm{g} \mathrm{Cr}$ in the urine of subject $\mathrm{S}$, on the 2nd day that $\mathrm{Cr}_{2} \mathrm{O}_{3}$ was ingested, suggested that some $\mathrm{Cr}$ had been absorbed. This was not confirmed by the balance studies, but in these only $6 \mathrm{~d}$ pooled urines could be estimated. In his extensive review on chromium, Mertz (I969) stated that he did not know of any reports of oral toxicity of trivalent chromium. Moreover, Whitby \& Lang (I960) as well as Davignon et al. (I968) reported no evidence of toxicity in their experience of using $\mathrm{Cr}_{2} \mathrm{O}_{3}$; the latter workers used a dose of $300 \mathrm{mg} / \mathrm{d}$, one-fifth of that used by Whitby \& Lang ( 1960 ) and in this study, and it is planned in future studies to use the smaller amount.

Scott \& Humphreys ( 1962 ) were able to assess the dispersion of $\mathrm{Cr}_{2} \mathrm{O}_{3}$ along the alimentary tract of cats, after killing the animals. In our subjects the close association between the excretion of $\mathrm{Ca}, \mathrm{Mg}$ and $\mathrm{Cr}$ in the faeces suggested that the $\mathrm{Cr}_{2} \mathrm{O}_{3}$ had become well mixed with the intestinal contents. Alvarez (I950) and Davenport (I96I) supported the idea that each day about one-sixth of the material entering the colon passed through to be defaecated and was augmented by about half the contents of 
the caecum. If such a pool of intestinal residues existed, $\mathrm{Cr}_{2} \mathrm{O}_{3}$ would have to be administered for many days before a state of equilibrium would be reached, since the $\mathrm{Cr}_{2} \mathrm{O}_{3}$ ingested in the first few days would be mixed with intestinal contents remaining from the previous 2 or 3 d. Likewise the elimination of the $\mathrm{Cr}_{2} \mathrm{O}_{3}$ after its administration ceased would be gradual, since the $\mathrm{Cr}_{2} \mathrm{O}_{3}$ in the intestinal pool would be diluted by incoming food residues. The existence of such a pool of intestinal residues seemed to be supported by several observations in our studies: quantitative recovery of the dose of $\mathrm{Cr}_{2} \mathrm{O}_{3}$ given on the Ist day took 3-4d, although the marker was detected in the faeces on the 2nd day. Six days were required before a steady state was reached when the output of the marker equalled the intake, which confirmed the advisability of administering the marker for the entire length of the $6 \mathrm{~d}$ preliminary period, which unfortunately was not done in this study. Further, subject $G$, who was not noticeably constipated, retained between 4 and $7 \mathrm{~g} \mathrm{Cr}_{2} \mathrm{O}_{3}$ from the 6th day of $\mathrm{Cr}_{2} \mathrm{O}_{3}$ administration, and the stools of subject $R$, who defaecated daily, still contained $\mathrm{Cr}_{2} \mathrm{O}_{3} 7 \mathrm{~d}$ after the dose had been taken. Although there was no direct evidence that $\mathrm{Cr}_{2} \mathrm{O}_{3}$ had not been selectively retained it seemed more likely that the retention of $\mathrm{Cr}_{2} \mathrm{O}_{3}$, and also of $\mathrm{Ca}$ and $\mathrm{Mg}$, was principally a simple consequence of constipation.

In short-term experiments there is uncertainty about whether a steady state has been attained and whether it is permissible to correct for variations in faecal output. It might seem preferable to analyse the exact faecal output from a particular period of feeding, but unfortunately this is impossible because of the mixing with residues from other periods. A rough method of demarcation can be achieved by the first appearance of an intermittent marker like brilliant blue, but this also becomes spread within the bowel (Lutwak \& Burton, 1964). This method alone gave unsatisfactory results for $\mathrm{Ca}$ and $\mathrm{Mg}$ balances, although it gave some indication of the transit time of food through the alimentary tract. By using brilliant blue in addition to chromic oxide, the advantages of the two types of marker may be combined, and their combination probably permits the faecal output of $\mathrm{Ca}$ and $\mathrm{Mg}$ to be measured, as closely as is possible, in a metabolic balance study.

We are particularly grateful to the subjects for their willing co-operation. One of us (S. J. S.) was supported by a grant from the Nuffield Trustees, whom we thank. The equipment for our study was provided by the Research Committee of the New Zealand University Grants Committee and by the Nuffield Trustees; we thank Dr A. D. Campbell, Chemistry Department, University of Otago, for use of an atomic absorption spectrophotometer until our own was delivered.

\section{REFERENCES}

Alvarez, W. C. (1950). An Introduction to Gastro-enterology 4th ed., p. 6r7. London: W. Heinemann. Borgström, B., Dahlqvist, A., Lundh, G. \& Sjövall, J. (1957). F. clin. Invest. 36, 1521.

Davenport, H. W. (I96I). Physiology of the Digestive Tract p. 207. Chicago: Year Book Medical Publishers, Inc.

Davignon, J., Simmonds, W. J. \& Ahrens, E. H. Jr (I968). F. clin. Invest. 47, 127.

Dawson, J. B. \& Heaton, F. W. (1961). Biochem. F. 80, 99.

Elkinton, J. R. \& Danowski, T. S. (1955). The Body Fluids p. 569. Baltimore: The Williams and Wilkins Co.

Feldman, F. J., Knoblock, E. C. \& Purdy, W. C. (1967). Analytica chim. Acta 38, 487. 
Figueroa, W. G., Jordan, T. \& Bassett, S. H. (1968). Am. F. clin. Nutr. 21, 1239.

Hargreaves, T. \& Rose, G. A. (r965). Clin. Sci. 28, 537.

Isaksson, B. \& Sjögren, B. (1967). Proc. Nutr. Soc. 26, 1o6.

Lusk, G. (1931). The Elements of the Science of Nutrition 4th ed., p. 46. Philadelphia \& London: W. B. Saunders, Co.

Lutwak, L. \& Burton, B. T. (1964). Am. F. clin. Nutr. 14, 109.

McCance, R. A. \& Widdowson, E. M. (1942). F. Physiol., Lond. ror, 44.

Mertz, W. (1969). Physiol. Rev. 49, 163.

Rampone, A. J. (1968). Am. F. Physiol. 214, 1370.

Rose, G. A. (1964). Gut 5, 274.

Schroeder, H. A. (1 968). Am. \%. clin. Nutr. 21, 230.

Scott, P. P. \& Humphreys, E. R. (r962). Proc. Nutr. Soc. 21, xiii.

Sollmann, T. (1926). A Manual of Pharmacology 3 rd. ed., p. 140. Philadelphia and London: Clarendon Press.

Swindells, Y. E., Holmes, S. A. \& Robinson, M. F. (1968). Br. F. Nutr. 22, 667.

Whitby, L. G. \& Lang, D. (1960). F. clin. Invest. 39, 854 .

Williams, C. H., David, D. J. \& Iismaa, O. (1962). F. agric. Sci., Camb. 59, $38 \mathrm{r}$.

Willis, J. B. (1961). Analyt. Chem. 33, 556. 